\title{
IMPROVING THE UNDERSTANDING OF CONTENT ON READING FOR TOEFL THROUGH YOUTUBE VIDEOS
}

\author{
Luqman Al Hakim ${ }^{1}$, Sumardiono ${ }^{2}$ \\ Universitas Slamet Riyadi \\ e-mail: luqmanalhakim@unisri.ac.id
}

\begin{abstract}
The study aims at describing the use of video based on global view on education in reading for TOEFL lesson to improve the students' reading skill and to internalize the values of mental revolution for the students of English education program at Universitas Slamet Riyadi. The research method is a collaborative action research. There are four phases in conducting the research: planning, action, observation, reflection, and revising the plan. The subject of the research is $2^{\text {nd }}$ and $4^{\text {th }}$ semester students of English education program at Universitas Slamet Riyadi, however in this article,the writers intend to describe the findings on reading for TOEFL lesson ( $4^{\text {th }}$ semester). The techniques in collecting the data are observation, questionnaire, and document analysis. Meanwhile, the techniques in analyzing the data are qualitative and quantitative analyses. The qualitative data analysis consists of data data reduction, data display, and drawing conclusion. And the quantitative data analysis is through mean score in every cycle. Research findings show that in the reading for TOEFL lesson, the mean score for pre-test was 38.7 . It was improved become 72.5 in the $1^{\text {st }}$ cycle. Finally, in the $2^{\text {nd }}$ cycle, the meanscore was 73.2. Meanwhile, another finding in terms of internalizing the values of mental revolution was that the students are able to find and conceive the values found in the videos and the texts, such as professionalism, creativity, working together, and nationalism values.
\end{abstract}

Key words: Collaborative Action Research, Reading for TOEFL, Mental Revolution.

\begin{abstract}
Abstrak
Tujuan penelitian ini diantaranya adalah untuk mendeskripsikan penggunaan media video berbasis pendidikan berwawasan global dalam pembelajaran bahasa Inggris (reading for TOEFL) untuk meningkatkan ketrampilan membaca para mahasiswa dan internalisasi nilainilai revolusi mental bagi para mahasiswa Program Studi Pendidikan Bahasa Inggris FKIP UNISRI. Metode penelitian ini adalah penelitian tindakan kelas kolaboratif. Ada empat langkah dalam melaksanakan penelitian ini, diantaranya perencanaan (planning), tindakan dan pengamatan (action and observation), refleksi (reflection), dan merevisi perencanaan (revising the plan). Subyek penelitian ini adalah mahasiswa semester II dan IV program studi Pendidikan Bahasa Inggris FKIP UNISRI sebab terdapat mata kuliah membaca pada semester tersebut, namun pada artikel ini, penulis hendak memaparkan deskripsi hasil penelitian pada mata kuliah reading for TOEFL semester IV. Teknik pemerolehan data penelitian ini adalah observasi, kuesioner, dan analisis dokumen. Sedangkan teknik analisis data penelitian ini adalah data reduction, data display, dan drawing conclusion. Hasil penelitian ini adalah pada perkuliahan reading for TOEFL, nilai rata-rata pre-test adalah 38,7, kemudian meningkat menjadi 72,5 pada siklus pertama, dan menjadi 73,2 pada siklus kedua, kemudian terkait dengan internalisasi nilainilai revolusi mental, mahasiswa mampu menemukan dan memahami nilai-nilai tersebut didalam video dan teks, yaitu nilai-nilai profesionalisme, kreatifitas, gotong royong, dan cinta tanah air.
\end{abstract}

Kata Kunci: Penelitian Tindakan Kelas Kolaboratif, Reading for TOEFL, Video. 


\section{PENDAHULUAN}

A. Latar Belakang Masalah

Di era sekarang, bahasa Inggris berperan sebagai bahasa resmi secara internasional, lingua franca, dan media untuk mempelajari inovasi-inovasi perkembangan ilmu pengetahuan dan teknologi. Hal tersebut senada dengan British Council (2013: 5) bahwa ... English now allows the rapid crosspollination of ideas and innovation around the world, and the development of a new kind of supranational single market in knowledge and ideas. Dari penjelasan tersebut dapat disimpulkan bahwa dengan penguasaan bahasa Inggris, seseorang akan mampu mempelajari ide/ gagasan, inovasiinovasi, dan perkembangan ilmu pengetahuan global.

Untuk mencapai kemampuan mempelajari ide, inovasi, dan ilmu pengetahuan, diperlukan ketrampilan membaca teks berbahasa Inggris yang memadai. Nayton (2013: 1) mengemukakan bahwa ada dua komponen menunjukkan bahwa pembaca memiliki ketrampilan yang memadai dalam membaca, yaitu (1) capacity to read the words on the page accurately dan (2) simultaneously the capacity to understand or comprehend the message or content being read. Dengan kata lain, kecakapan dalam membaca kata-kata dalam setiap halaman secara akurat dan hal tersebut bersamaan dengan kecakapan untuk memahami pesan yang sedang dibaca merupakan ketrampilan membaca yang wajib dikuasai oleh pembaca untuk mempelajari ide/ gagasan, inovasiinovasi, dan perkembangan ilmu pengetahuan global.

Para mahasiswa program studi pendidikan bahasa Inggris FKIP UNISRI memiliki kendala dalam membaca. Menurut hasil pra-survey yang telah dilaksanakan pada tanggal 17 Mei 2017 terhadap mahasiswa semester II, IV, dan VI program studi Pendidikan bahasa Inggris FKIP UNISRI, ada beberapa permasalahan yang sedang mereka dihadapi. Berikut jenis permasalahan dan prosentasenya.

Tabel 1.1. Hasil Pra- Survey tentang Problematika Membaca Mahasiswa Program Studi Pendidikan Bahasa Inggris FKIP UNISRI Tahun 2017

\begin{tabular}{|c|c|c|c|c|}
\hline \multirow[t]{2}{*}{ No } & \multirow[t]{2}{*}{$\begin{array}{c}\text { Jenis Problematika } \\
\text { Membaca }\end{array}$} & \multicolumn{3}{|c|}{$\begin{array}{c}\text { Prosentase } \\
\text { Problematika } \\
\text { Membaca } \\
\text { Mahasiswa } \\
\text { PBI UNISRI Tahun } \\
2017\end{array}$} \\
\hline & & $\begin{array}{l}\text { Smt } \\
\text { II }\end{array}$ & $\begin{array}{l}\text { smt } \\
\text { IV }\end{array}$ & $\begin{array}{l}\text { mhs } \\
\text { VI }\end{array}$ \\
\hline 1 & $\begin{array}{l}\text { Menemukan ide } \\
\text { pokok }\end{array}$ & $25 \%$ & $35 \%$ & $26 \%$ \\
\hline 2 & $\begin{array}{l}\text { Menemukan } \\
\text { informasi rinci }\end{array}$ & $10 \%$ & $8 \%$ & $4 \%$ \\
\hline 3 & $\begin{array}{l}\text { Memahami makna } \\
\text { kata }\end{array}$ & $60 \%$ & $50 \%$ & $65 \%$ \\
\hline 4 & Memahami referensi & $5 \%$ & $7 \%$ & $5 \%$ \\
\hline
\end{tabular}

Berdasarkan hasil pra-survey tersebut, menemukan ide pokok dan informasi rinci yang ada didalam teks, dan memahami makna kata dan referensi merupakan permasalahan utama yang dihadapi mahasiswa program studi pendidikan Bahasa Inggris. Disamping itu terdapat permasalahan lain dalam membaca teks berbahasa Inggris, yaitu: (1) memiliki penguasaan kosakata yang terbatas, sehingga mereka membuka kamus ketika membaca teks, (2) membaca teks hanya dilaksanakan untuk memenuhi tugas mata kuliah, (3) lebih menyukai membaca teks berbahasa Inggris yang mudah difahami, (4) bermalas-malasan dalam membaca teks, dan (5) jarang mempraktikkan strategi membaca ketika membaca teks, padahal sudah diajarkan ketika perkuliahan.

Hasil pra-survey juga menunjukkan bahwa terdapat empat penyebab permasalahan siswa dalam membaca: (a) para mahasiswa membaca hanya sebagai kegiatan untuk mengerjakan tugas perkuliahan sehingga peningkatan ketrampilan membaca mereka lambat; (b) para mahasiswa lebih menyukai aktifitas berbicara berbahasa 
Inggris ketika perkuliahan daripada aktifitas membaca, sehingga diperlukan integrasi antara membaca dan berbicara ketika perkuliahan; (c) para mahasiswa jarang menggunakan strategi membaca dalam membaca teks berbahasa Inggris, dan (d) pengajar mata kuliah reading kurang dalam membimbing dan memonitor perkembangan ketrampilan membaca mereka.

Dari permasalahan dan penyebab masalah tersebut, diperlukan suatu solusi untuk mengatasi hal tersebut, yaitu dengan media video. Ismaili (2013: 1) mengemukakan bahwa movies attract students' attention, present language in a more natural way that found in coursebooks. What is more important movies offer a visual context aids which help students understanding and improve their learning skills. Dengan kata lain, video dalam bentuk film mempu menarik perhatian siswa dan mempraktikkan bahasa secara alami seperti yang terdapat dalam buku. Disamping itu video menawarkan audio dan visual untuk membantu siswa memahami dan meningkatkan ketrampilan berbahasa Inggris.

Dari pemaparan tersebut diatas, peneliti melaksanakan penelitian tindakan kelas (PTK) dengan judul Implementasi Pembelajaran Bahasa Inggris Dengan Media Video Berbasis Pendidikan Berwawasan Global Untuk Meningkatkan Ketrampilan Membaca Dan Sebagai Internalisasi NilaiNilai Revolusi Mental (Studi Pada Mahasiswa Program Studi Pendidikan Bahasa Inggris Fkip Unisri).

\section{TINJAUAN PUSTAKA}

\section{Video}

Video merupakan salah satu bentuk media pembelajaran multimedia. Berikut ini beberapa teori tentang pengertian video dan manfaat video dalam pembelajaran Alhakim (2015: 6) mengemukakan bahwa media video merupakansuatu media yang berbentuk gambar dan suara serta tulisan yang bertujuan untukmemaparkan suatu fenomena dalam bentuk yang jelas dan lengkap. Selanjutnya, Menurut Business Dictionary (2016: 1) mengemukakan bahwa video merupakan visual multimedia source that combines a sequence of images to form a moving picture. Disamping itu, menurut Oxford Dictionaries (2016: 1) video merupakan the recording, reproducing, or broadcasting of moving visual images and a recording of moving visual images made digitally or on videotape. Dari beberapa pengertian tersebut dapat disimpulkan bahwa video merupakan media multimedia yang terbentuk dari kombinasi gambar dan suara yang runtut untuk memaparkan fenomena dalam bentuk yang jelas dan lengkap.

Selanjutnya, video memiliki beberapa manfaat. Menurut Herron Dkk, 1995: 775 didalam Ismaili (2013: 122) mengemukakan manfaat video dalam pembelajaran:

"Video is lauded for contextualizing language (i.e., linking language form to meaning) and depicting the foreignculture more effectively than other instructional materials. Videotapes permit students to hear native speakersinteracting in everyday conversational situations and to practice important linguistic structures. Unlikeaudiocassettes, video's visual dimension is thought to reduce ambiguities present in native speaker voicesand to motivate students to want to learn the foreign language"

Dari kutipan tersebut, video menggambarkan penggunaan bahasa Inggris sesuai dengan konteks dan menggambarkan budaya asing lebih efektif daripada materi pembelajaran lainnya. Disamping itu video menyajikan praktik interaksinative speakersehari-hari dan bentuk struktur bahasa yang penting, dan video mampu mengurangi ambiguitas dalam memahami interaksi berbahasa Inggris dan untuk memotivasi siswa untuk belajar bahasa Inggris. 


\section{Ketrampilan Membaca Teks Report}

Membaca (reading) merupakan salah satu ketrampilan dalam berbahasa Inggris. Berikut ini pengusul memaparkan definisi membaca, dan makna, susunan paragraf, dan elemen bahasa pada teks report.

Menurut kamus besar bahasa Indonesia online (2016), membaca merupakan melihat serta memahami isi dari apa yang tertulis (dengan melisankan atau hanya dalam hati). Sedangkan menurut Macmillan Dictionary (2016) membaca merupakanthe process of recognizing written or printed words andunderstanding their meaning. Dengan kata lain membaca merupakan proses mengenal dan memahami makna tulisan. Selanjutnya, Bernhardt (1987) didalam Chung (2012: 3) mengemukakan bahwa membaca merupakan the process of relating new, or incoming information to information already stored in memory (background knowledge). Dengan kata lain, membaca merupakan proses berkaitan dengan hal baru atau informasi yang akan datang dengan informasi yang sudah tersimpan dalam memori. Dari ketiga pengertian tersebut dapat disimpulkan bahwa membaca merupakan proses mengenal dan memahami materi tertulis baik dalam bentuk kata, frase, klausa, kalimat, maupun paragraf.

Berikut ini merupakan jenis-jenis ketrampilan membaca menurut Brown (2001: 307) sebagai berikut:

1. Discriminate among the distinctive graphemes and orthographic patterns of English.

2. Retain chunks of language.

3. Process writing at an efficient rate of speed to suit the purpose.

4. Recognize a core of words, and interpret word order patterns and their significance.

5. Recognize grammatical word classes (nouns, verbs, etc) systems (e.g. tense, agreement, pluralization), patterns, rules, and elliptical forms.

6. Recognize that a particular meaning may be expressed in different grammatical forms.

7. Recognize cohesive devices in written discourse and their role in signaling the relationship between and among clauses.
8. Recognize the rhetorical forms of written discourse and their significance for interpretation.

9. Recognize the communicative functions of written texts, according to form and purpose.

10. Infer context that is not explicit by using background knowledge.

11. Infer links and connections between events, ideas, etc., deduce causes and effects, and detect such relations as main idea, supporting idea, new information, given information, generalization, and exemplification.

12. Distinguish between literal and implied meanings.

13. Detect culturally specific references and interpreted them in a context of the appropriate cultural schemata.

14. Develop and use a battery of reading strategies such as scanning and skimming, detecting discourse markers, guessing the meaning of words from context, and activating schemata for the interpretation of texts.

Menurut K-6 modules (2007: 227) teks report ... are used to present information about something. They generally describe an entire class of things, whether natural or constructed: mammals, the planets, rocks, plants, computers, countries of the region, transport, and so on. Dengan kata lain, teks report digunakan untuk menyampaikan informasi tentang sesuatu hal yakni, hal-hal yang bersifat khusus, baik itu alami maupun buatan, semisal planet, batu,tanaman, computer dan sebagainya. Sedangkan struktur atau urutan paragraf pada teks report sebagai berikut:

a. a general statement identifying the subject of the information report, perhaps defining and classifying it;

b. description ('bundles' of information relating to, for example, features, behaviour, or types).

Teks report tersusun dari elemen bahasa sebagai berikut:

a. use of general nouns, eg hunting dogs, rather than particular nouns, eg our dog;

b. use of relating verbs to describe features, eg reptiles are scaly animals; 
c. some use of action verbs when describing behaviour, eg emus cannot fly;

d. use of timeless present tense to indicate usualness, eg Komodo dragons usually weigh more than $160 \mathrm{~kg}$. The Arctic tern migrates from the Arctic to the Antarctic;

e. use of technical terms, eg Isobars are lines drawn on a weather map;

$f$. use of paragraphs with topic sentences to organise bundles of information;

g. repeated naming of the topic as the beginning focus of the clause.

\section{METODE PENELITIAN}

\section{A. Pendekatan Penelitian}

Pendekatan pada penelitian ini menggunakan penelitian tindakan kelas. Sedangkan jenis penelitian tindakan kelas yang digunakan adalah penelitian tindakan kelas kolaborasi (collaborative action research). Jenis penelitian ini digunakan sebab pengusul beranggotakan dua orang sehingga berkolaborasi dalam pelaksanaan penelitian.

\section{B. Setting dan Subyek Penelitian}

Setting pada penelitian ini adalah ruang kuliah fakultas keguruan dan ilmu pendidikan bahasa Inggris Universitas Slamet Riyadi, yaitu ruang London. Ruangan tersebut terletak di lantai satu gedung pusat Bahasa UNISRI. Fasilitas ruangan tersebut antara lain LCD proyektor, AC, tempat duduk kapasitas 30 kursi, sebuah meja tulis, dan layar monitor LCD.

Sedangkan subyek pada penelitian ini adalah para mahasiswa regular semester II dan IVprogram studi pendidikan bahasa Inggris tahun akademik 2017/2018, namun pada artikel ini peneliti mendeskripsikan hasil penelitian pada semester IV mata kuliah reading for TOEFL yang berjumlah 25 mahasiswa. Pemilihan subyek penelitian tersebut didasarkan pada hasil observasi, wawancara, dan pemberian angket terhadap para mahasiswa sehingga disimpulkan bahwa ketrampilan membaca mereka perlu untuk diteliti serta hasil analisis dokumen yang menunjukkan bahwa nilai ketrampilan membaca mereka masih dibawah kriteria ketuntasan minimal (KKM).

\section{Langkah- Langkah Penelitian}

Metode penelitian pada penelitian ini adalah penelitian tindakan kelas. Burns (1999: 33) mengemukakan bahwa ada empat langkah didalam penelitian tindakan kelas, yaitu

1. Perencanaan (planning),

Perencanaan merupakan kegiatan awal penelitian yang terdiri dari perumusan masalah, dan menyusun rencana penelitian berupa rencana pembelajaran, penyebaran angket, dan wawancara.

2. Tindakan dan pengamatan (acting and observing),

Tindakan dan pengamatan merupakan kegiatan melaksanakan hal-hal yang sudah direncanakan. Ada beberapa kegiatan yang dilaksanakan pada tahapan ini, yaitu memberikan pre-test, pengajaran, dan posttest.

3. Refleksi (reflection), dan

Refleksi merupakan aktifitas untuk mengetahui kelebihan dan kekurangan selama pelaksanaan penelitian

4. Revisi perencanaan (revising a plan)

Revisi perencanaan merupakan kegiatan memperbaiki perencanaan yang sudah direncanakan pada tahap awal berdasarkan kelemahan yang terjadi ketika pelaksanaan penelitian. Berikut ini merupakan bagan proses pelaksanaan penelitian tindakan kelas:

\section{Teknik Pengumpulan Data}

Teknik pengumpulan data pada penelitian ini adalah tes dan non-tes. Tes merupakan instrumen untuk mengukur suatu fenomena. Pada penelitian ini jenis tes yang digunakan adalah tes essay untuk mengukur ketrampilan menulis para mahasiswa. Tes tersebut akan dilaksanakan sebelum penelitian (pre-test), setelah siklus 1 (post-test 1) dan setelah siklus 2 (post test 2).

Sedangkan teknik non-tes merupakan alat ukur untuk mengetahui sejauh mana ketrampilan siswa didalam menulis dan kondisi siswa dalam proses pembelajaran. Pada penelitian ini peneliti menggunakan teknik non-tes berupa pengamatan, kuesioner, dan analisis dokumen, sebagai berikut:

1. Pengamatan dilaksanakan sebelum penelitian untuk mengetahui kondisi para mahasiswa dalam proses pembelajaran dan ketika penelitian untuk mengetahui 
progress yang dialami oleh para mahasiswa ketika proses pembelajaran.

2. Kuesioner diberikan sebelum dan sesudah penelitian. Sebelum penelitian bertujuan untuk mengetahui kondisi nyata para mahasiswa dalam mengikuti proses pembelajaran. Setelah penelitian bertujuan untuk mengetahui perkembangan ketrampilan dan kondisi mahasiswa setelah pelaksanaan tindakan.

3. Analisis dokumen diperlukan untuk mendukung hasil pengamatan, interviu, dan kuesioner sebab dokumen merupakan bukti sejauh mana ketrampilan siswa didalam menulis dan kondisi siswa ketika proses pembelajaran.

Didalam penelitian tindakan kelas, diperlukan suatu teknik untuk mengetahui keabsahan data, yaitu teknik triangulasi. Burns (1999: 163) menyatakan bahwa the aim of triangulation is to gather multiple perspectives on the situation being studied. Hal tersebut bermakna bahwa tujuan triangulasi adalah untuk memperoleh beragam pandangan pada suatu keadaan yang sedang dipelajari. Dengan kata lain, suatu keadaan didalam proses penelitian diketahui melalui beragam cara, antara lain dengan pengamatan, kuesioner, interviu, dan analisis dokumen. Setelah data tersebut diperoleh, langkah selanjutnya adalah membandingkan hasil pemerolehan data untuk mengetahui persamaan dan perbedaan hasil data. Dari persamaan data yang diperoleh, maka data tersebut dapat dikatakan valid, sedangkan dari perbedaan data, hal tersebut dapat melengkapi data yang kurang lengkap sehingga akan terbentuk data yang lengkap. Disamping itu perbedaan data perlu dievaluasi dalam bentuk pengecekan data dilapangan berupa intervieu maupun analisis

\section{E. Teknik Analisis Data}

Miles and Huberman (1994: 10-11) mengemukakan bahwa ada tiga kegiatan dalam menganalisis data, yaitu data reduction, data display, dan conclusion drawing/verification. Berikut ini perjelasan dari kegiatan tersebut:

1. Data reduction

Data reduction merupakan the process of selecting, focusing, simplifying, abstracting, and transforming the data that appears in written-up field notes or transcriptions. Dengan kata lain, reduksi data merupakan proses pemilihan, fokus, penyederhanaan, abstraksi, dan transformasi data yang tertulis dalam catatan lapangan atau transkrip. Dalam hal ini, transkrip hasil observasi, interviu, dan angket merupakan alat pemerolehan data yang akan melalui proses reduksi data. Disamping itu Data reduction merupakan a form of analysis that sharpens, sorts, focuses, discard, and organizes data in such a way that "final" conclusion can be drawn and verified. Dengan kata lain reduksi data merupakan bentuk analisis yang mempertajam, fokus, dan mengelompokkan data sebagai hasil dari kesimpulan dan ferifikasi. Data dapat direduksi melalui pemilihan, dan rangkuman atau parafrase.

\section{Data display}

Data display merupakan an organized, compressed assembly of information that permits conclusion drawing and action. Dengan kata lain data display (penyajian data) merupakan organisasi dan penyederhanaan informasi yang melatarbelakangi kesimpulan dan tindakan.

\section{Conclusion drawing}

Conclusion drawing merupakan ...to decide what things mean- is noting regularities, patterns, explanations, configurations, causal flows, and propositions. Dalam tahapan ini peneliti mengemukakan atau menginterpretasi makna yang berupa istilah, penjelasan, konfigurasi, atau pernyataan.

\section{HASIL PENELITIAN DAN PEMBAHASAN}

Pertemuan pertama siklus pertama mempelajari materi Main Idea, Main Topic, dan Main Purpose Questions, menyaksikan video dan membaca teks berjudul "Gifford Pinchot" dan "Richard Hoe". Dukungan konten dari kedua sumber belajar tersebut mendukung mahasiswa mempelajari materi pembelajaran. Informasi didalam kedua teks tersebut tersaji dengan lengkap (meskipun itu tampak sebuah parafrase), organisasi ide dan konten tersusun secara kronologis, dan ditunjang dengan tatabahasa serta kosakata tingkat advance learners menyuguhkan input 
bacaan yang menunjang kemudahan dalam menpraktikkan ketrampilan menemukan ide pokok, kalimat pendukung, referensi, dan makna kata.

Nilai-nilai revolusi mental yang terdapat didalam kedua sumber belajar tersebut dapat difahami dan ditemukan dengan baik oleh mahasiswa. Konten yang bersifat temuan dalam bidang media informasi dan kehutanan cukup memberikan gambaran tentang bentuk-bentuk dan sejauh mana nilai-nilai revolusi mental ini diimplementasikan dalam bidang tersebut. Proses mencapai temuan yang bersifat kronologis didukung dengan data yang lengkap tentang rincian aktifitas yang mereka kerjakan merinci bentuk nilai-nilai revolusi mental yang dapat difahami oleh mahasiswa dengan mudah.

Pertemuan kedua siklus pertama mempelajari tentang Details, Negative, dan Scanning Items didukung dengan video dan teks berjudul "The Wright Brothers". Informasi bacaan yang tersusun secara kronologis dengan akurasi bahasa inggris yang baik memberikan input informasi rinci yang memadai bagi mahasiswa. Hal tersebut didukung dengan visualisasi yang menunjukkan realitas proses terwujudnya temuan "The Wright Brothers" dalam bentuk pesawat. Dukungan informasi dari video tersebut mendukung kemudahan mahasiswa dalam memahami bacaan sebab mereka mengaitkan antara isi bacaan yang tidak mereka fahami dengan isi video yang sudah disaksikan.

Nilai-nilai revolusi mental yang terdapat didalam video dan teks tersebut memaparkan secara implisit tentang proses terwujudnya hasil karya "The Wright Brothers". Kecermatan dan pengalaman mahasiswa dalam membaca menjadi modal dasar diperolehnya nilai-nilai tersebut. Isi bacaan yang bersifat ringkasan didukung dengan isi video mampu membentuk informasi yang lengkap dan jelas sehingga pemahaman akan urut-urutan aktifitas dan rincian dari aktifitas tersebut menjadi lebih mudah dicermati dan difahami.

Pertemuan pertama siklus kedua mempelajari materi Details, Negative, dan Scanning Items, menyaksikan video dan membaca teks tentang "Mesa Verde". Informasi didalam video tentang profil "Mesa Verde" memiliki cakupan yang bersifat umum dibanding konten teks berjudul "Mesa Verde" yang bersifat knonologis dan terperinci. Sajian video sebelum membaca bacaan cukup membantu memberikan deskripsi awal dan visualisasi nyata tentang "Mesa Verde" sehingga mahasiswa terbantu dalam memahami bacaan secara lebih terperinci.

Nilai-nilai revolusi mental didalam kedua sumber belajar tersebut memaparkan informasi yang mengandung nilai-nilai yang bersifat implisit. Video tersebut memaparkan informasi secara umum, sehingga mahasiswa perlu menyimpulkan tentang nilai-nilai revolusi mental yang terkandung didalamnya, semisal liputan tentang wujud bukit batu yang diukir menjadi rumah yang termasuk kategori nilai-nilai kreatifitas dan gotong royong. Sedangkan isi teks yang bersifat terperinci, lengkap, dan kronologis memberikan gambaran pada mahasiswa agar lebih teliti dan cermat dalam menemukan dan memahami nilai-nilai tersebut sebab sajian teks memiliki tingkat kesulitan bahasa yang lebih tinggi dari bacaan pada pertemuan sebelumnya.

Pertemuan kedua siklus kedua mempelajari materi Details, Negative, dan Scanning Items, menyaksikan video dan membaca teks berjudul "Dorothea Dix". Dua video tentang "Dorothea Dix" memberikan contoh nyata secara terperinci perlakukan rumah sakit dimasa lalu yang menangani pasien penyandang disabilitas dengan tidak manusiawi sedangkan isi teks tersebut tidak menjelaskan hal tersebut namun lebih kepada kronologi perjalanan hidup beliau hingga mampu mewujudkan emansipasi bagi penyandang disabilitas. Karakteristik bacaan tersebut menunjang peningkatan ketrampilan mahasiswa dalam menemukan informasi rinci sebab teks tersebut hanya berisi dua paragraf sehingga mayoritas kalimat merupakan informasi rinci. Hal tersebut memudahkan mahasiswa menemukan letak informasi yang dimaksud sesuai dengan pertanyaan yang ada didalam soal latihan.

Nilai-nilai revolusi mental disajikan lebih lengkap didalam video sebab nilai-nilai didalamnya lebih mudah dicerna tanpa 
memahami bahasa. Namun pemahaman bahasa lisan yang memadai juga diperlukan dalam pemerolehan informasi yang menyeluruh yang ada didalam video. Video dalam format black and white terkesan klasik dan yang paling penting memberikan deskripsi faktual tentang apa yang sebenarnya terjadi dimasa itu sehingga pembaca merasa empati seolah-olah sedang berasa dimasa itu. Peranan seolah menjadi observant participant ini membuat kepekaan pembaca untuk memahami nilai-nilai revolusi mental lebih mudah.

\section{KESIMPULAN}

Kesimpulan dari penelitian ini adalah sebagai berikut:

1. Mahasiswa mampu menemukan dan memahami nilai-nilai revolusi mental yang terdapat didalam bacaan dan video sebab dengan kedua sumber informasi tersebut, saling melengkapi dan memberikan visualisasi yang bersifat nyata dan fakta.

2. Mahasiswa mampu memahami dan menemukan ide pokok, informasi rinci, referensi, dan makna kata dalam kalimat sebab tersedia kiat dan strategi untuk hal tersebut.

1. 3. Motivasi mahasiswa dalam mengikuti pembelajaran meningkat sebab mereka menyaksikan video yang menarik dan berkaitan dengan konten bacaan yang dibaca sehingga proses kegiatan pembelajaran dapat terlaksana dengan lancar dan mampu mencapai tujuan pembelajaran yang sesuai kurikulum.

\section{DAFTAR PUSTAKA}

Arinawati, Arinawati (2012) The Use of Video to Improve Students' Reading Comprehension on Advertisement Text (a Classroom Action Research with the Eighth Grade Students' of MTs NU Al-Hikmah Mijen Semarang in the Academic Year of 2011/2012).Undergraduate (S1) thesis, IAIN Walisongo.

British Council. (2013). The English Effect The impact of English, what it's worth to the UK and why it matters to the world. Diakses dari https://www.britishcouncil.org /sites/default/files/english-effect-report-v2.pdf pada hari Senin 17 Mei 2016.

Burns, Anne. (1999). Collaborative Action Research for English language Teachers. Cambridge. Cambridge University Press

Business Dictionary. (2016). Video. Diakses pada http://www.businessdictionary.com/definition/video. html pada hari Rabu 18 Mei 2016.

Ho Van Chung, M. A. (2012). A Study of Reading Comprehension Problems in English Encountered by First Year Students of Faculty of Vietnamese Studies at Hnue. Diakses dari http://foe.hnue.edu.vn/Portals/1/Ho\%20Chung.pdfpada hari Rabu 18 Mei 2016.

Hakim, Luqman Al. (2015). Implementasi pembelajaran bahasa Inggris dengan Media Video Youtube Berbasis Lingkungan untuk Meningkatkan Kompetensi Menulis Teks Eksplanasi dan sebagai Internalisasi Nilai-Nilai Kesadaran Lingkungan. Penelitian Dosen Pemula DIKTI.

Ismaili. (2013). The Effectiveness of Using Movies in the EFL Classroom- A Study Conducted at South East European University. Academic Journal of Interdisciplinary Studies.Published by MCSER-CEMAS-Sapienza University of Rome Vol 2 No 4 May 2013.

Kamus Besar Bahasa Indonesia Online. (2016). Diakses dari http://kbbi.web.id/bacapada hari Rabu 18 Mei 2016

Khalidiyah, Hanifah. (2015). The Use of Animated Video in Improving Students' Reading Skill. S1 thesis, Universitas Pendidikan Indonesia.

Kominfo. 2017. Revolusi Mental: Membangun Jiwa Merdeka Menuju Bangsa Besar. Diakses dari https://kominfo.go.id/index.php/content/detail/5932/Revolusi+Mental\%3A+ Membangun+Jiwa+Merdeka+Menuju+Bangsa+Besar/0/artikel_gpr 
Kompas. 2014. Jokowi dan Arti "Revolusi Mental" diakses dari http://nasional.kompas.com /read/2014/10/17/22373441/Jokowi.dan.Arti.Revolusi.Mental.

Naurin. Rufaida. (2014). Peningkatan Pemahaman Membaca Pada Siswa Dalam Teks Narratif Menggunakan Video Animasi (Penelitian Tindakan Kelas Pada Kelas XI IPA 1 di MA Nahdlatul Muslimin Kudus Tahun Ajaran 2013/2014). Skripsi, Program Study Bahasa Inggris. Fakultas Keguruan dan Ilmu Pendidikan. Universitas Muria Kudus.

Nayton, M. (2013). Factors that Contribute to Successful Reading Comprehension. Diakses dari http://www.attadaleps.wa.edu.au/useruploads/files/reading_comprehension_ document.pdf pada hari minggu 15 Mei 2016.

Mappalotteng, Abdul Muis. (2011) Paradigma Pendidikan Berwawasan Global dan Tantangannya. Diakses dari http://ft-unm.net/medtek/Jurnal_MEDTEK_Vol.3_No.2_ Oktober_2011_pdf/Jurnal\%20PAk\%20Muis.pdf pada hari Rabu 18 Mei 2016.

Macmillan Dictionary. (2016). Diakses dari http://www.macmillandictionary.com/dictionary/british/readingpada hari Rabu 18 Mei 2016.

Miles, M,B dan Huberman, A,M. (1994). Qualitative Data Analysis Second Edition. California: SAGE Publications Inc.

Oxford Dictionaries. (2016). Oxford Dictionary Language Matters. Diakses dari http://www.oxforddictionaries.com/definition/english/video pada hari Rabu 18 Mei 2016.

Putra Putri Indonesia. 2017. Revolusi Mental: Bagaimana Mewujudkannya?. Diakses dari http://www.putra -putri-indonesia.com/revolusi-mental.html

Revolusi Mental. 2015. 8 Prinsip Revolusi Mental. Diakses dari http://revolusi mental.go.id/ tentang-gerakan/nilai-nilai-strategis-revolusi-mental

Revolusi Mental. 2015. Nilai-nilai Strategis Revolusi Mental. Diakses dari http://revolusi mental.go.id/ tentang-gerakan/nilai-nilai-strategis-revolusi-mental

Sudarsono, M, I. (2014). Identitas ASEAN, Bahasa Inggris, dan Indonesia.diakses dari http://balaibahasa.upi.edu/wpcontent/uploads/downloads/thumbnails/2014/05/IDENTIT AS-ASEAN.BAHASA-INGGRIS.INDONESIA-2014-05-12.pdf pada hari minggu 15 Mei 2016.

Undang- Undang No. 14 tahun 2005 tentang Guru dan Dosen diakses dari http://kepri.kemenag.go.id/file/file/UndangUndang/lysc1391498449.PDF pada hari Rabu 18 Mei 2016. 